\title{
Corymbose and Annular Pattern in Secondary Syphilis with Concomitant Chancre on Penis: Can it Be a Manifestation of Early Latent Syphilis
}

\author{
(1) Subhasmita Baisya, (1) Subhadeep Mallick, (1) Olympia Rudra, (1) Pramit Nandy, (1) Aniruddha Mandal, \\ (D) Aishwarya Prakash
}

IPGMER and SSKM Hospital, Department of Dermatology, SSKM Kolkata, India

\section{ABSTRACT}

Secondary syphilis (SS) usually involves skin, mucous membrane, lymphnodes, eyes, bones. A rare but characteristic manifestation of SS is corymbose pattern where is a large central papule and a few small ones at the periphery. The papules may be present in annular configuration. Here we present a case who has only few corymbose and annular lesions of SS over face with no lesions in other areas of body, with concomitant chancre over penis

Keywords: Secondary syphilis, Corymbose and annular pattern, Early latent

\section{Introduction}

Secondary syphilis (SS) is a sexually transmitted infection caused by the spirochete Treponema pallidum, subspecies pallidum. It can manifest as macular, papular, pustular syphilide. Papular form can manifest as annular, corymbose pattern which is characteristics of SS. Physicians unaware of its protean manifestations may easily overlook its atypical presentation. After healing of SS lesions, patient enters in phase of latency, but relapses occur in $25 \%$ cases during latent phase among untreated syphilitics [1]. Clinical relapses conform to a picture of SS, though the disease is less extensive. Occasional occurrence of a relapsing lesion resembling a primary chance at the site of initial primary chancre has been referred as "chancre redux. Here we report a case who has only few corymbose and annular lesions of SS over face with no lesions in other areas of body, with concomitant chancre redux over penis.

\section{Case Report}

A 27-year-old, unmarried male patient presented with asymptomatic annular lesions over chin (Figure 1) and left sided cheek (Figure 2) and a penile lesion (Figure 3) for last six weeks. He had history of unprotected sexual intercourse with an unknown male. He had no history of similar lesions over his body in past. But he gave history of painless penile lesions eight months back which was started after four weeks of unprotected sexual intercourse. On clinical examination, the papular lesions were arranged in annular configuration, there was a one central large papule which was surrounded by multiple small satellite papules resembling corymbose lesion. The lesions were painless, non-pruritic. There was whitish to slightly reddish non tendered, non-pruritic plaques and ulcers over glans penis and undersurface of prepuce. Mucosa, lymph node and systemic examination were normal. No other cutaneous lesions were present. Venereal disease research laboratory was positive at 1:64 and Treponema pallidum hemagglutination assay was positive. $\mathrm{He}$ 
was negative for HIV 1 and 2. Biopsy from facial lesions revealed aggregate of lymphocytes with few epithelioid cells and plenty of plasma cells in upper dermis (Figures 4, 5).

\section{Discussion}

Atypical cutaneous manifestations of the SS rash may be more common than generally assumed and include (but are not limited to) annular, nodular, pustular, psoriasiform, circinate, bullous, rupioid, framboesiform, nodular-ulcerative, ulceronecrotic, granulomatous, vesicular, follicular, pigmentary (leukoderma syphiliticum and
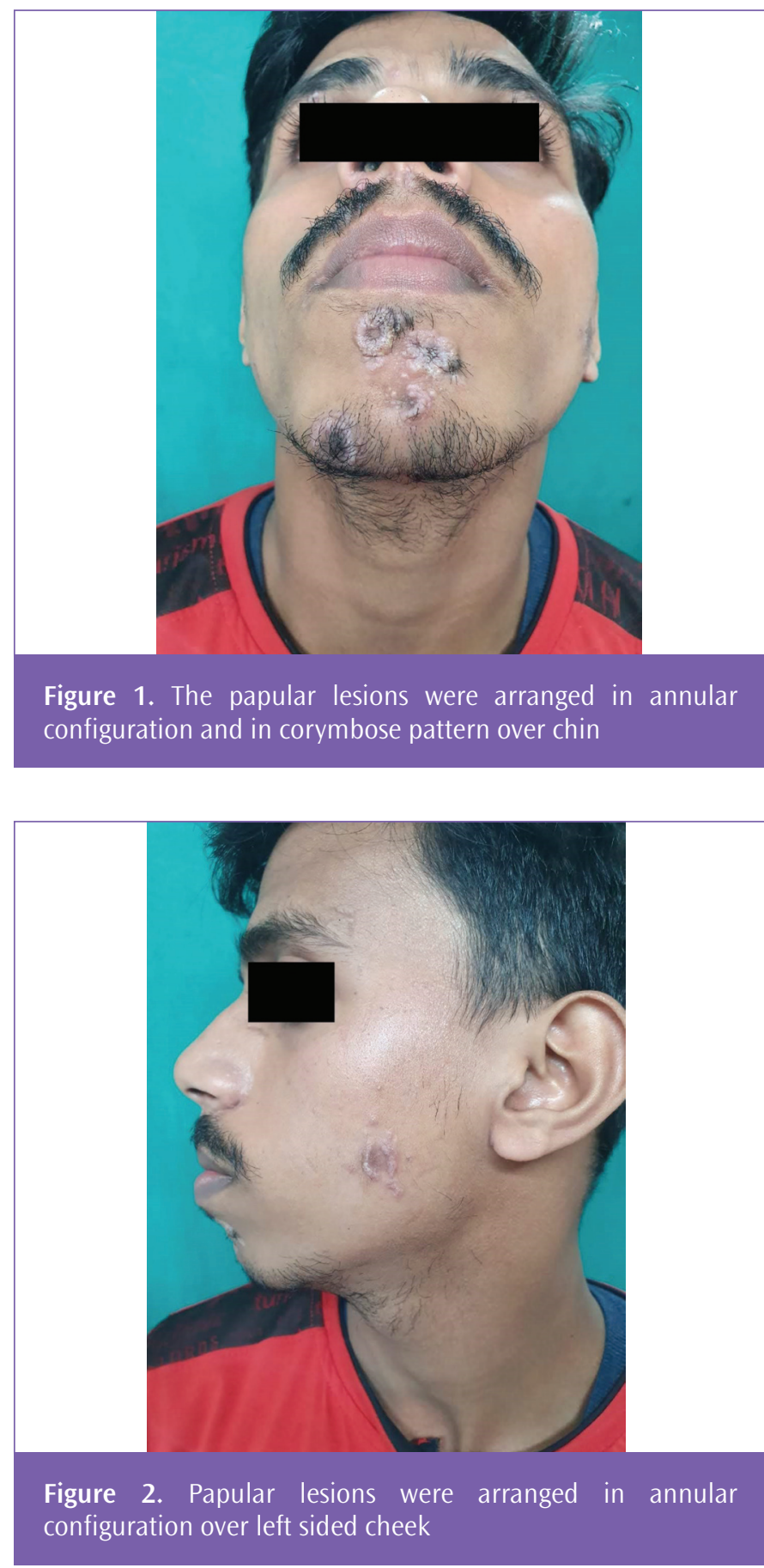

pigmentary syphilide), and corymbose lesions [2]. A corymbose (or corymbiform) arrangement (from the Greek kórymbos, cluster of fruits or flowers) comprises a central greater papule surrounded by smaller satellite lesions. Corymbose syphilis may present as single lesion [3] or several lesions [4]. Adamson reported in the early twentieth century that corymbose syphilis was a well-known though somewhat rare type of syphilide [5]. After many years of syphilology practice, Fournier considered syphilide papuleuse en corymbe a rare and bizarre presentation of SS that was "very significant due to its singularity" [6].
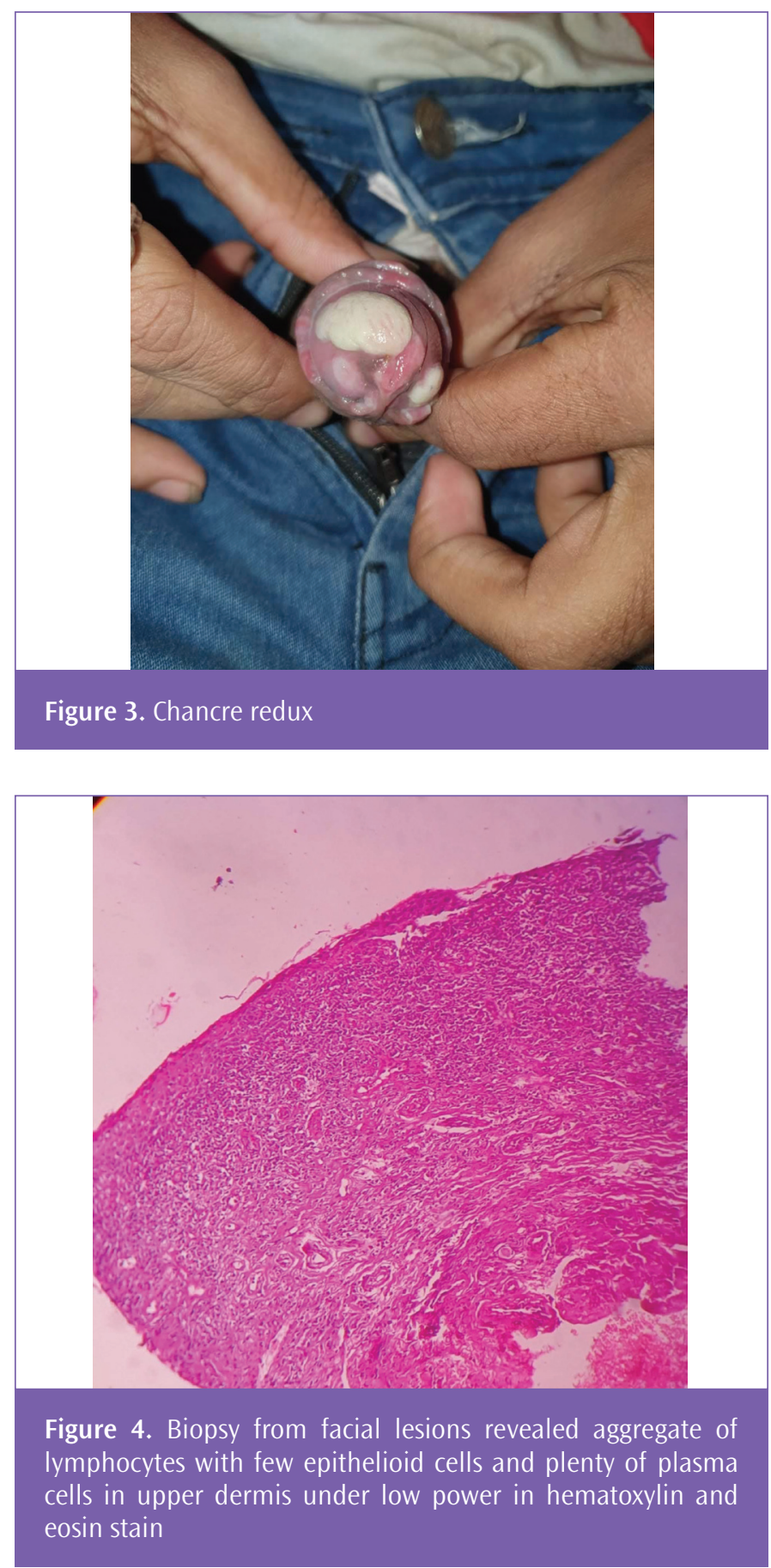


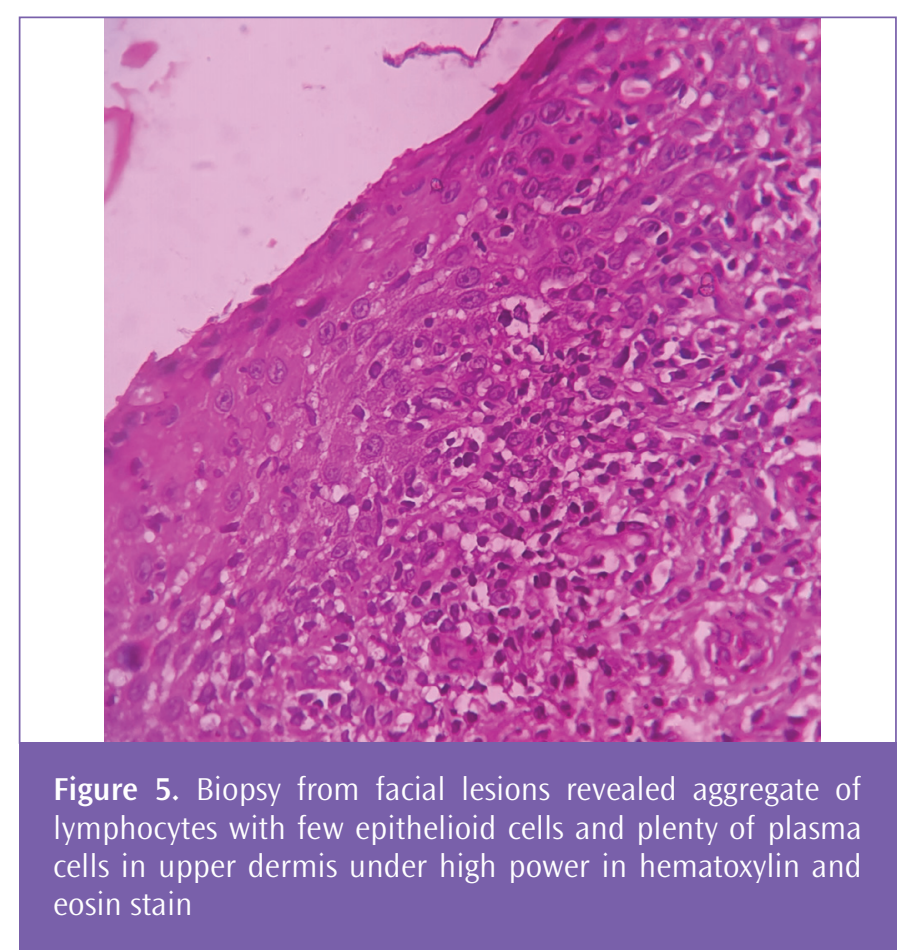

Our case is important because our case has only few reports of corymbose pattern in literature and our patient has also concomitant chancre redux on penis which could indicate an early latent syphilis. Failure to recognize and appropriately treat syphilitic lesions may have ominous consequences, since the lesions will undergo spontaneous remission, entering into a latent stage, and life-threatening complications may eventually ensue.

\section{Ethics}

Informed Consent: Consent form was filled out by all participants.

Peer-review: Internally peer-reviewed.

\section{Authorship Contributions}

Surgical and Medical Practices: S.B., S.M., O.R., P.N., A.M., A.P., Concept: S.B., S.M., P.N., A.M., A.P., Design: S.B., S.M., P.N., A.P., Data Collection or Processing: S.B., S.M., O.R., P.N., A.M., A.P., Analysis or Interpretation: S.B., S.M., O.R., P.N., A.M., A.P., Literature Search: S.B., S.M., O.R., P.N., A.M., A.P., Writing: S.B., S.M., A.M.

Conflict of Interest: No conflict of interest was declared by the authors.

Financial Disclosure: The authors declared that this study received no financial support.

\section{References}

1. Misra RS, Kumar J. Syphilis: Clinical features and natural course. In: Sharma VK, editor. Sexually transmitted diseases and HIV/AIDS, 2nd ed. New Delhi: Viva Books Private Limited, 2009:262-288.

2. Baughn RE, Musher DM. Secondary syphilitic lesions. Clin Microbiol Rev 2005;18:205-216.

3. Shimizu S, Yasui C, Tajima Y, Tsuchiya K. Unusual cutaneous features of syphilis in patients positive for human immunodeficiency virus. Clin Exp Dermatol 2010;35:169-172.

4. Velasco-Tamariz V, Rodríguez-Peralto JL, Ortiz-Romero P. Corymbiform Lesions in a Young Healthy Man. JAMA Dermatol 2017;153:1317-1318.

5. Adamson HG. Small Follicular Syphilide of the Corymbose Type. Proc R Soc Med 1910;3:1.

6. Fournier A. Traité de la syphilis. Tome I: période primaire - période secondaire. Paris: J. Rueff; 1906. 